\title{
PSYCHE.
}

\section{A PRELIMINARY SYNOPSIS OF THE HARVEST-SPIDERS (PHALANGIIDAE) OF MISSISSIPPI.}

\author{
BY CLARENCE M. WEED, HANOVER, N. H.
}

The present paper is based upon a collection of Phalangiidae kindly sent me at various times during the last three years by my brother, Mr. Howard Evarts Weed, of the Mississippi Agricultural College. Nearly all of the specimens were taken in the vicinity of the College, which is located in Oktibbeha County, a little north of the center of the State, so that the northern and southern extremities of Mississippi are not represented. This probably accounts, in part at least, for the fact that in the large number of specimens collected only three species are found.

The most remarkable thing connected with these phalangiids is the large size of their bodies and the length of their legs. Each form is the southern representative of a northern species in which the body is smaller and the legs are larger. I presume this variation in size is due to the longer period of growth and feeding at the south, but the discussion of variations is not the purpose of the present paper.

\section{Family PHALANGIIDAE.}

\section{Subfamily Phalanginnae.}

Arachnids having the body composed of a single piece, and long, slender legs. The teguments are not coriaceous, though often quite solid. The segments are only indicated by striae, which are often obsolete. There are five ventral abdominal segments; a single anal piece, and two distinct lateral pores on upper margin of cephalothorax. The maxillary lobe of the palpus has two tubercles. The two eyes are placed upon a blunt tubercle (the eye-eminence) on the median line of the cephalothorax not far from its front margin.

The three Mississippi forms all belong to the single genus Liobunum, the principal characters of which are the following :-

Anterior and lateral borders of the cephalothorax smooth. Eye eminence relatively small; smooth, or rarely provided with small, slightly distinct tubercles; widely separated from the cephalic border. Lateral pores small, oval, and marginal. Anal piece large, transverse-oval or semi-circular, much wider than long. Mandibles short, similar in the two sexes; first joint furnished at the base below with an acute tooth. Palpi simple; femur, patella and tibia without any process and without projecting angles; maxillary lobe provided at the base with two strong, conical teeth. Maxillary lobe of the second pair of legs very long, nearly straight from the base, not attenuated, directed mesad nearly horizontally, and united on the ventromeson to the lobe from the opposite side without forming a sensible angle; the two together lightly arched on the cephalic border, and forming an even curve. Sternal piece large, slightly contracted between the 
fourth pair of coxae, gradually enlarging and obtusely truncate cephalad. Feet very long and slender; tibia of the second pair with a few false articulations. Palpal claw denticulate.

The three forms described below may be distinguished as follows:-

Body and legs cinnamon-brown.

L. ventricosum hyemale.

Eye eminence with a regular row of tubercles over each eye; dorsum with no black marking in males, and indistinct one in females. . . L. politum magnum.

Eye eminence with very few tubercles; a distinct black, longitudinal marking on dorsum.

L. vittatum.

\section{Liobunum vittatum (Say).}

The Striped Harvest-spider. Plates I I, I2.

Phalangium vittatum. Say, Journ. Phila. Acad., II, p. 65, I82 I ; Wood, Comm. Essex Inst., VI, pp. 20-2 I.

Liobunum vittatum. Weed, Amer. Nat. XXI, p. 935 ; XXVI, p. 999.

Male. - Body $7 \mathrm{~mm}$. long; $4 \mathrm{~mm}$. wide. Palpi $7 \mathrm{~mm}$, long. Legs: first, $44 \mathrm{~mm}$.; second, $89 \mathrm{~mm}$.; third, $45 \mathrm{~mm}$.; fourth, 64 $\mathrm{mm}$.

Dorsum reddish-brown, with a dark central marking, commencing at eye eminence and extending backward to the ultimate or penultimate abdominal segment. Contracting slightly near the anterior margin of abdomen, then gradually expanding until about the beginning of the posterior third of the abdomen, where it again slightly contracts. Ventrum slightly paler than dorsum, both finely granulate. Eye eminence a little wider than high, black above, canaliculate, with small black tubercles over the eyes. Mandibles light yellowish-brown, tips of claws black; second joint with short sparse hairs. Palpi long, reddish-brown; tarsal joints paler. Femur and patella arched, with two rows of rather blunt dark tubercles, on the outer ventro-lateral surface; femur also having a few small subobsolete ones on its dorsal surface. Tibia with a similar row on its outer ventro-lateral surface, a short row on the distal portion of its inner ventro-lateral surface, and a short row on the proximal portion of its ventral surface. Tarsus pubescent, with a row of short, blunt, black tubercles on its inner ventro-lateral surface, extending from the base to near the apex. Legs varying from light brown to black, but patella is generally black and tarsi brown, the other joints varying. Coxae reddishbrown, minutely tuberculate. Trochanters generally dark brown with minute scattered tubercles. Femora and patellae with rows of small spines. Tibiae with very short hairs. Shaft of genital organ slender, subcylindrical, not broadened distally, but bent at an obtuse angle and terminating in a very acute point.

Female. - Body 8-9 mm. long; 5-6 mm. wide. Palpi $5 \mathrm{~mm}$. long. Legs: first, 42 $\mathrm{mm}$. ; second, $90 \mathrm{~mm}$.; third, $43 \mathrm{~mm}$.; fourth, 6r $\mathrm{mm}$.

Besides its rounder body and much more robust appearance, it differs from the male as follows: Dorsum of a much darker shade of brown with less of the reddish tint, and the ventrum paler. Second joint of mandibles with fewer hairs. Palpi shorter, more slender, with the rows of tubercles on the tibia subobsolete, and that on the tarsus entirely wanting. Legs generally light brown with black annulations at the articulations. Ovipositor whitish with no dark color in apical rings.

This species in Central Mississippi evidently passes the winter in the egg state, the young hatching in March, April and probably the early part of May, becoming fully developed in July and living until October or November. Specimens taken during October are very deeply colored. The collections 
before me show very young to halfgrown forms taken 3 oth May, I89I; some approaching maturity collected during June ; and some fully developed but not fully colored taken in July. There appears to be but one brood a year so that the species has a very long feeding period.

In a recent paper in the American Naturalist (December, 1892) I have discussed at some length the geographical variations of this Striped Harvestspider.

Liobunum ventricosum hyemale, Weed. Plates I3, I4.

Phalangium ventricosum Wood, Comm. Essex inst., vi, 32.

Liobunum ventricosum (Wood). Weed, Amer. nat., xxiv, 918; Trans. Am. ent. soc., $\mathrm{XIX}, \mathrm{I} 88$.

Liobunum ventricosum hyemale Weed, Amer. nat., March, r893.

Male. - Body $9 \mathrm{~mm}$. long; $6 \mathrm{~mm}$. wide; palpi $8 \mathrm{~mm}$. long. Legs: first, $52 \mathrm{~mm}$.; second, ror $\mathrm{mm}$; third, $50 \mathrm{~mm}$.; fourth, 73 $\mathrm{mm}$. Body elongate, abdomen subconical. Dorsum, legs including trochanters cinnamon-brown, ventrum of a slightly lighter brown, sometimes grayish brown. Dorsum closely granulate with an indistinct darker marking, and numerous small grayish spots arranged in irregular transverse series. Eye eminence black, except at base; rounded, not canaliculate, smooth, or with a few small, acute tubercles. Palpi rather slender, with none of the angles prolonged; femur with a very few small spinous tubercles and hairs; patella strongly, and femur and tibia slightly, arched; coxae minutely tuberculate, tipped with white; trochanters and legs cinnamon rufous; tarsi dusky. Legs long and moderately robust. Genital organ of male "flat, nearly straight, slender at the basal portion, gradually widening and distally rather quickly expanded into a broad alate portion, and then abruptly contracted into a moderately robust, slightly curved point, which is placed at an angle to the rest of the shaft; at the base of the point a marked notch in the end of the shaft."

Female. - Body i i mm. long; $6.2 \mathrm{~mm}$. wide. Palpi $7 \mathrm{~mm}$. long. Legs : first, 48 mm.; second, $93 \mathrm{~mm}$; third, $46 \mathrm{~mm}$.; fourth, $68 \mathrm{~mm}$. Differs from the male in having a larger body, with the abdomen often greatly swollen.

This species passes the winter in a half-grown condition. The eggs are apparently laid during summer and hatch early in autumn. The length of the second pair of legs of young specimens, taken at the Agricultural College during October, I892, varied from 15 millimetres to 33 millimetres. The size of early spring specimens is represented in plate $\mathrm{I}_{4}$, fig. I ; and the structural details in fig. 2 of the same plate. Such forms are described as follows:-

Length $7 \mathrm{~mm}$; width $4 \mathrm{~mm}$. Legs : first, $32 \mathrm{~mm}$.; second, 6o mm.; third, $3 \mathrm{I} \mathrm{mm}$.; fourth, $45 \mathrm{~mm}$. Body soft. Dorsum smooth; mottled brown. A distinct dark central marking begins at eye eminence, and runs two-thirds of the way to the posterior extremity; it contracts near the anterior border of the abdomen, then expands in an even curve, and again contracts in a similar wayThere is a deep oblique sinus just back of each lateral pore of cephalothorax. On the abdomen are scattered dark spots, arrange in irregular transverse series. Eye eminence perfectly smooth; black about eyes with a light brown longitudinal central marking; slightly longer than high; not at all canaliculate. Mandibles light gray, with tips blackish : sparsely provided with short black hairs. Palpi slender; mottled grayish-brown; all the joints provided with short, black, stiff 
spinous hairs. Patella arched; its inner lateral distal angle produced into a pronounced conical tubercle. Tarsal claw distinctly pectinate. Ventral surface light gray. Legs long, rather stout; coxae light gray, remaining joints mottled cinnamon-brown.

The mature condition is reached early in summer. The Mississippi forms are somewhat larger than plate I3, fig. I, which represents a specimen from a more northern locality ; but the structural details are similar to those illustrated in fig. 2 of the same plate.

An account of the variations and synonymy of this species will be found in one of the earlier issues of the American Naturalist for 1893 .

Liobunum politum magnum, new subspecies.

Male. - Body $5 \mathrm{~mm}$. long; $4 \mathrm{~mm}$. wide; palpi $3.8 \mathrm{~mm}$. long. Legs : first, $40 \mathrm{~mm}$.; second, $80 \mathrm{~mm}$.; third, $40 \mathrm{~mm}$.; fourth, $5^{8}$ $\mathrm{mm}$. Dorsum granulate; varying from light cinnamon-brown to reddish brown, with no markings except occasionally a faint indication of the usual central marking. Eye eminence prominent, slightly constricted at base, more or less black above, canaliculate, with a regular curved series of small, acute, blackish spines over each eye. Mandibles brownish white; tips of claws black. Palpi slender, light brown, with femur and patella sometimes dusky; finely pubescent, with a subobsolete row of minute dark tubercles on the inner ventro-lateral surface of femur, and another row on the inner ventro-lateral surface of tarsus; joints slightly arched. Ventrum with coxae, including the membranous distal lateral tips, and generally the trochanters, varying from light brown to vermilion red. Legs with proximal portions light brown; distally dark brown or blackish.
Shaft of genital organ nearly straight, slender, flattened, canaliculate; distal portion very slightly expanded, then slightly contracted, and again expanded into a half spoon-shaped portion, and terminating in a small acute point.

Female. - Body $6.5 \mathrm{~mm}$. long; $4.5 \mathrm{~mm}$. wide; palpi, $3.6 \mathrm{~mm}$. long. Legs : first, 39 $\mathrm{mm}$.; second, $8 \mathrm{r} \mathrm{mm}$.; third, $39 \mathrm{~mm}$.; fourth, $57 \mathrm{~mm}$. Differs from the male in having a larger, rounder body; and in the color of the dorsum, which is brown, or reddish-brown, with a rather distinct, darker central marking and numerous whitish spots arranged more or less transversely. In some specimens the central marking and spots are obsolete. Apical rings of ovipositor white.

A few specimens of this form have been taken during June and July at the Agricultural College. A single female has also been collected at the same place in October. This is much more deeply colored than the others of this sex examined, being clear reddish brown, and having the central marking and white spots on dorsum obsolete. It is illustrated at plate ${ }_{5}$, fig. I, and the structural of the northern $L$. politum are shown in fig. 2 of the same plate.

\section{EXPLANATION OF PLATES.}

PLATE II.

Fig. I.-Liobunum vittatum. Male. Natural size.

2.-Parts of same. Magnified.

2a.-Body.

2b. -Eye eminence. Side view.

2c.-Eye eminence. Front view.

2d.-Palpus. Side view.

2e.-Claw of palpus. Side view.

3.-Liobunum vittatum dorsatum. Male from Dakota. Natural size. 
Psyche, 1893, vol. 6.

Plate II.

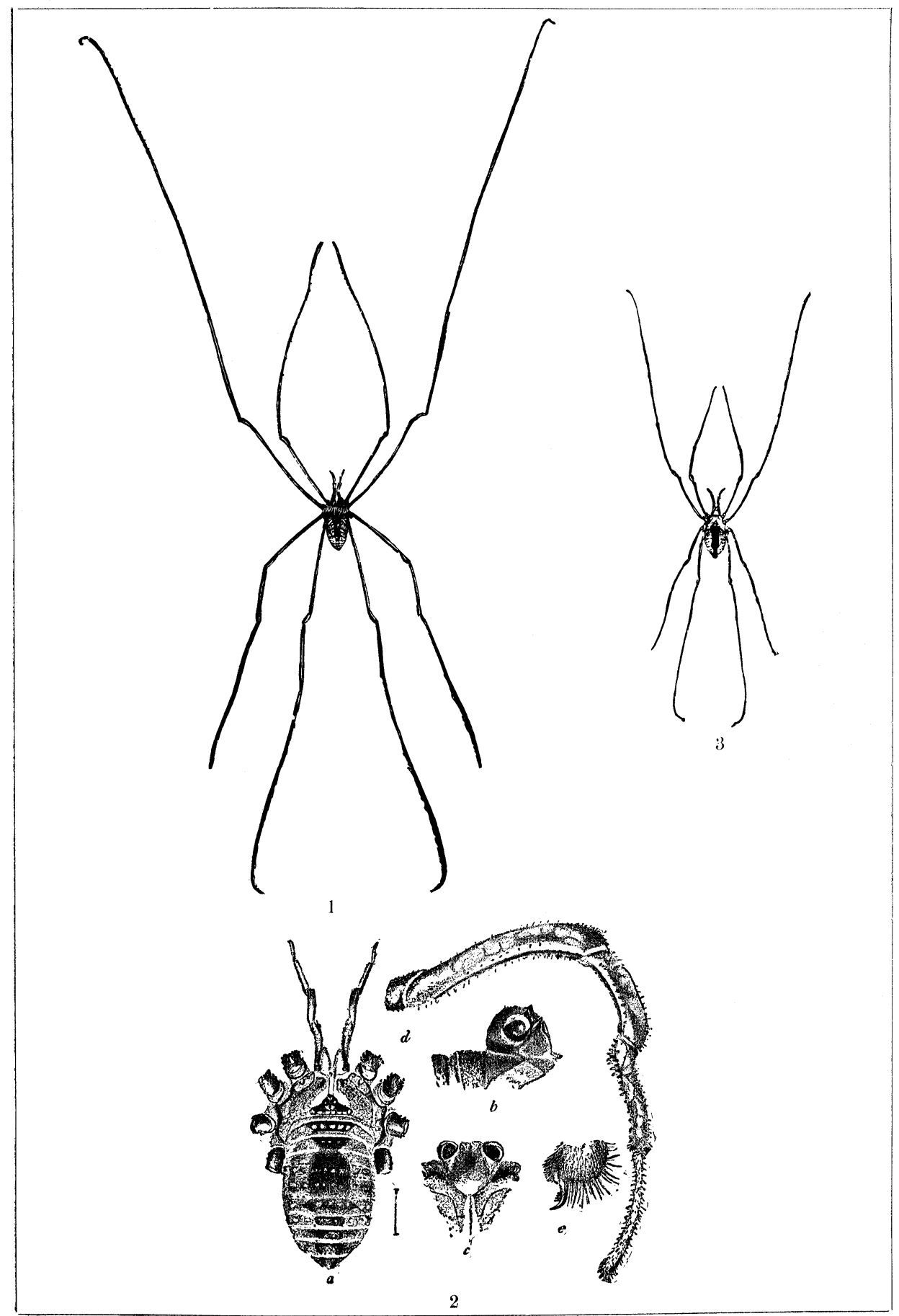

Liobunum vittatum (Say), $\delta$. 
Psyche, 1893, vol. 6.

Plate I2.

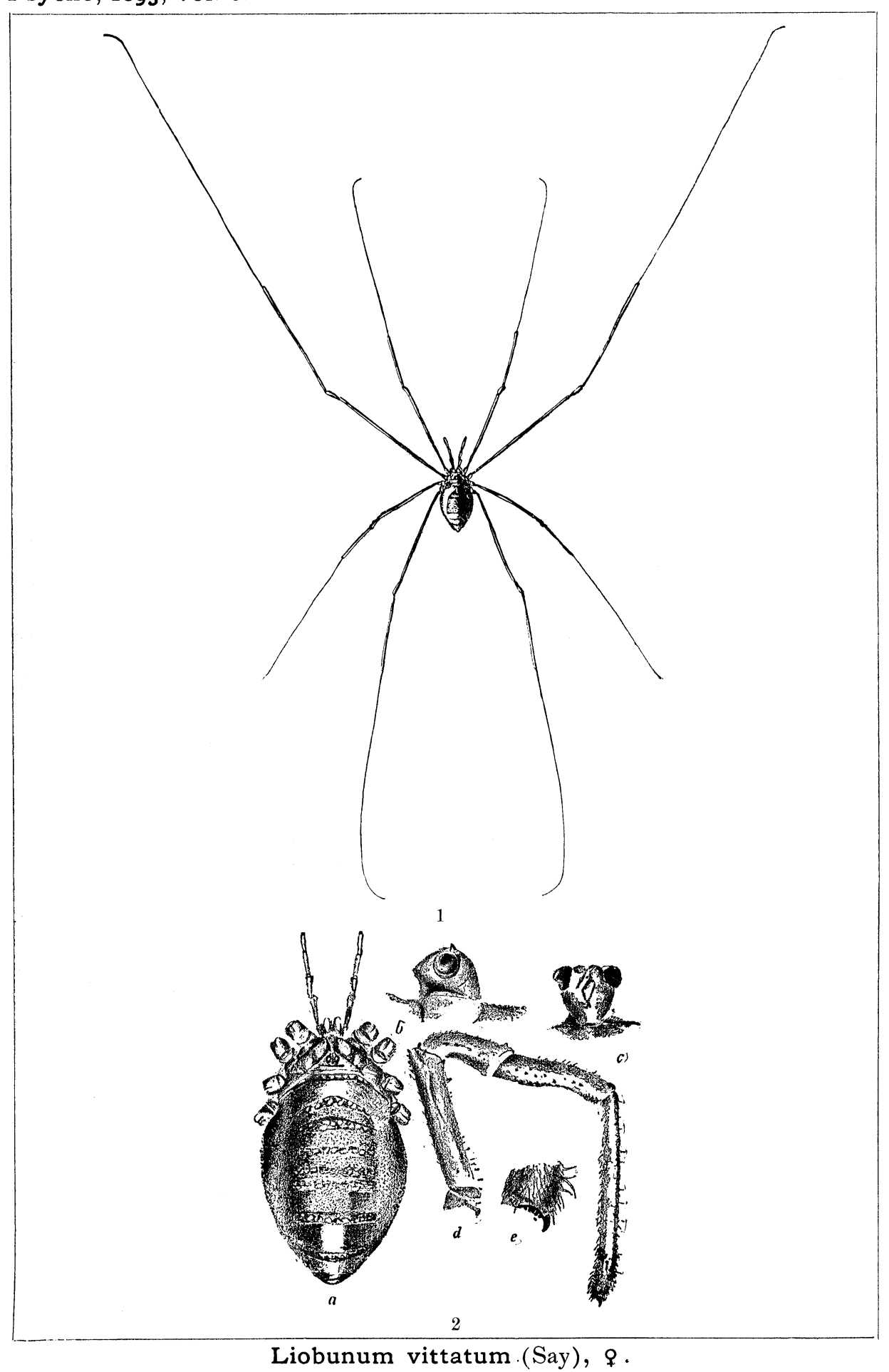


Psyche, 1893, vol. 6.

Plate 13.
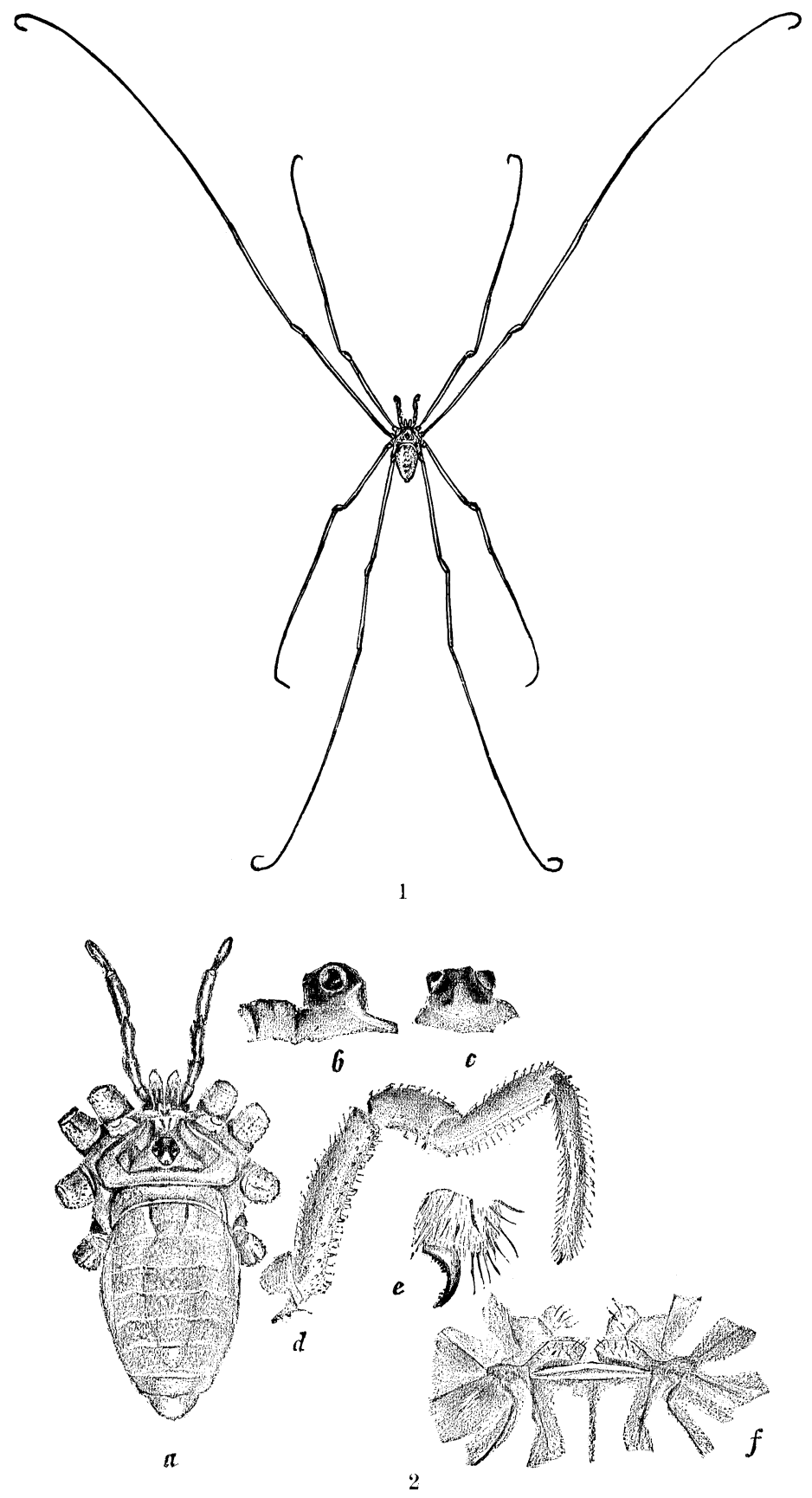

Liobunum ventricosum (Wood). 

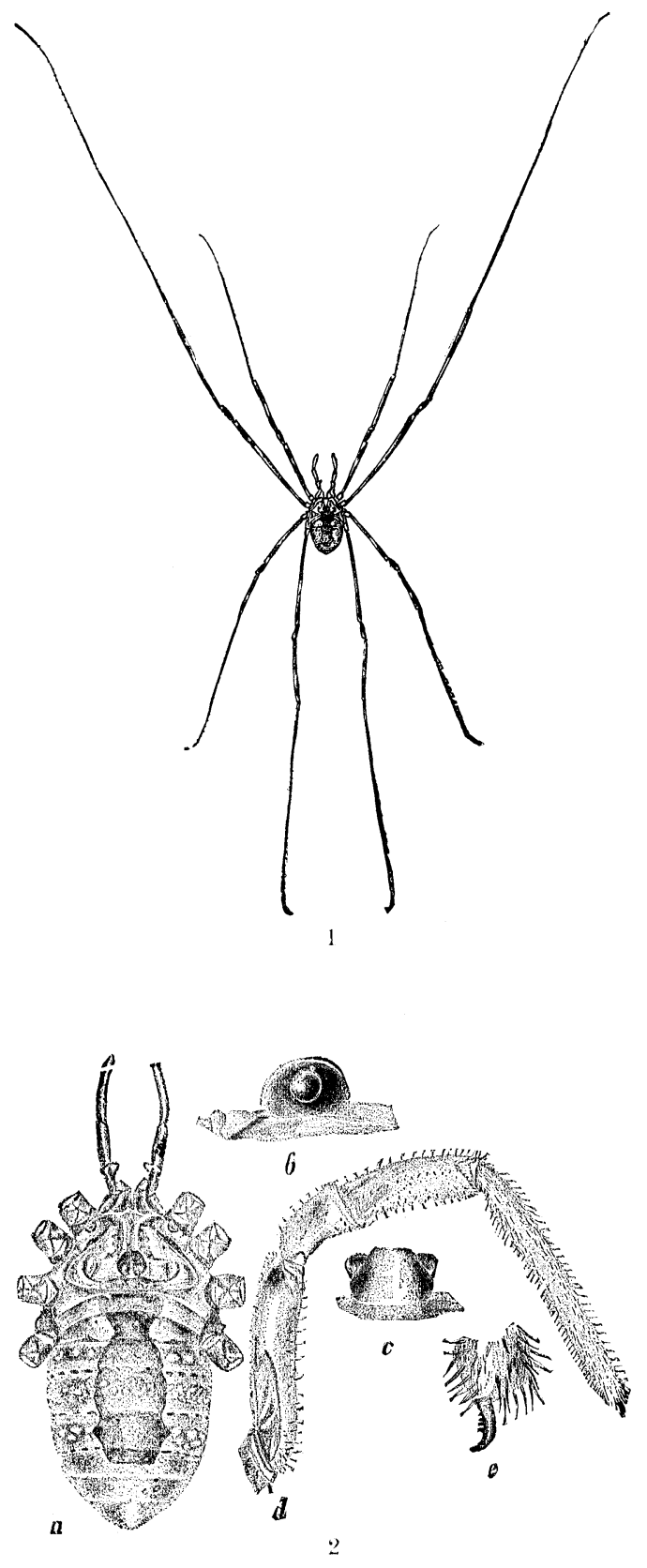

Liobunum ventricosum hyemale (Immature). 
Psyche, 1893, vol. 6.

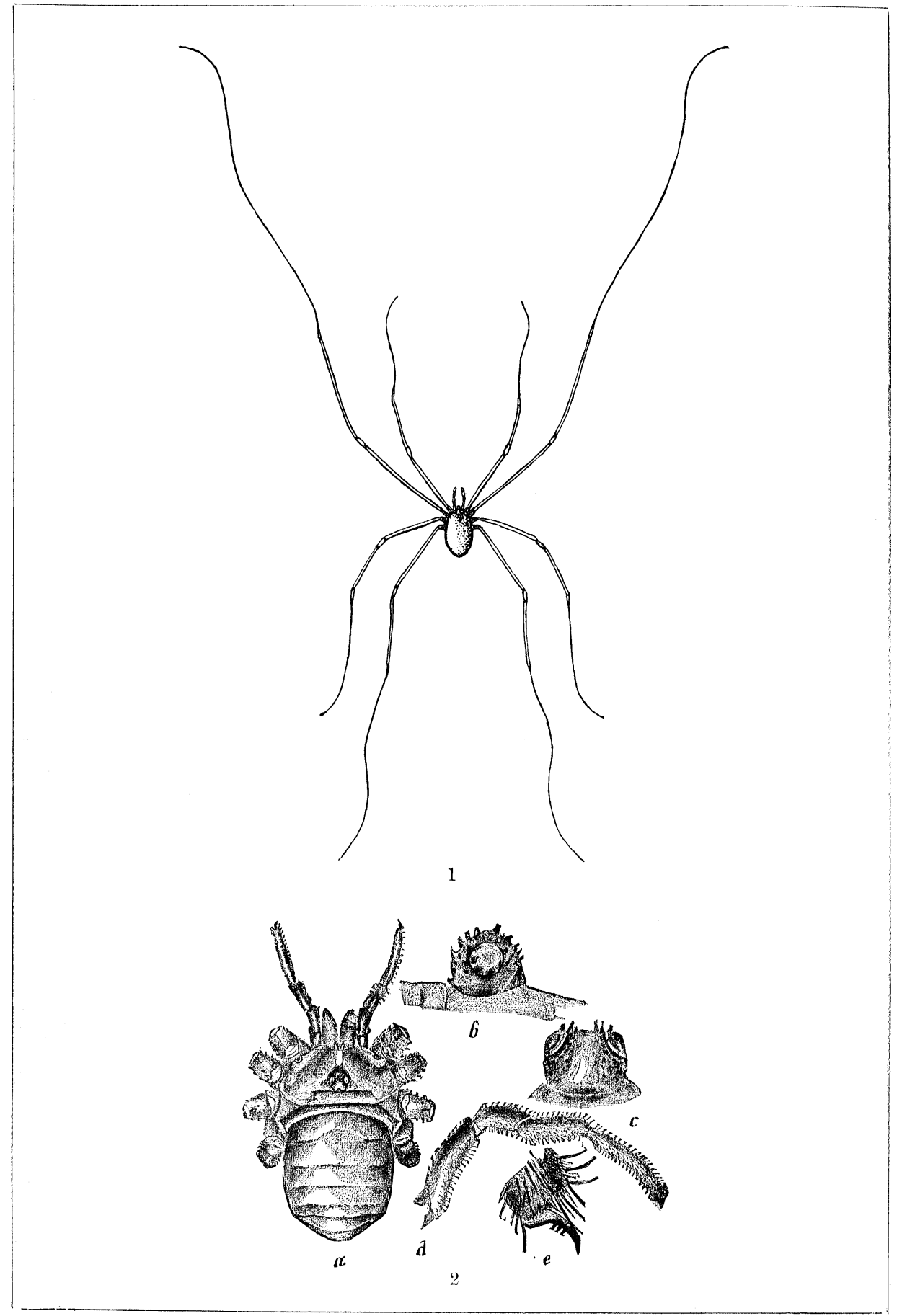

Liobunum politum and L. politum magnum. 
PLATE I2.

Fig. I.-Livbunum vittatum. Female. Natural size.

2.-Parts of same. Magnified.

2a.-Body.

2b.-Eye eminence. Side view.

2c.-Eye eminence. Front view.

2d.-Palpus. Side view.

2e.-Claw of palpus. Side view.

PlAte I3.

Fig. I.-Liobunum ventricosum (Wood) male. Natural size.

2.-Parts of same. Magnified.

2a.-Body.

2b.-Eye eminence. Side view.

2c.-Eye eminence. Front view.

2d.-Palpus. Side view.

$2 e$. - Claw of palpus. Side view.

2f.-Maxillary lobe of second pair of legs.
PLATE I4.

Fig. 1.-Liobunum ventricosum hyemale. Immature. Natural size.

2.-Parts of same. Magnified.

$2 a$.-Body.

2b.-Eye eminence. Side view.

2c.-Eye eminence. Front view.

2d.-Palpus. Side view.

$2 e$. - Claw of palpus. Side view.

PLATE 15 .

Fig. I.-Liobunum politum magnum. Female. Natural size.

2.-Liobunum politum. Parts of male. Magnified.

2a.-Body.

2b.-Eye eminence. Side view.

2c.-Eye eminence. Front view.

2d.-Palpus. Side view.

$2 e$. - Claw of palpus. Side view.

\title{
DESCRIPTION OF A NEW AND INTERESTING PHASIID-LIKE GENUS OF TACHINIDAE S. STR.
}

\author{
BY C. H. TYLER TOWNSEND, LAS CRUCES, N. MEX.
}

During the last year, I have received, among several lots of flies from New Hampshire, a number of specimens of a tachinid s. str., which I at first mistook for a phasiid of the genus Hyalomyia. Upon examination, recently, the distinctness of the form was at once realized, but the great resemblance in almost every detail save one was very surprising. This one detail will, however, always be sufficient to distinguish it, and that is the presence of macrochaetae on the abdomen, a character possessed by no phasiid.

From its extreme resemblance to
Hyalomyia, I propose to call the new genus Hyalomyorles. The species may be known as 17 . weedii, in honor of Dr. Weed, in whose sendings my attention was first called to this interesting form.

\section{IIyALOMYODES nov, gen.}

Head much like Iryalomyia; front very narrow, slightly widened at vertex, much more widened toward insertion of antennae, at narrowest about one ninth width of head in both sexes. Face widening from front at same angle as latter, so that the two opposite boundaries of the face and front diverge uniformly from each other from the narrowest part of the front to a point very near the oral 

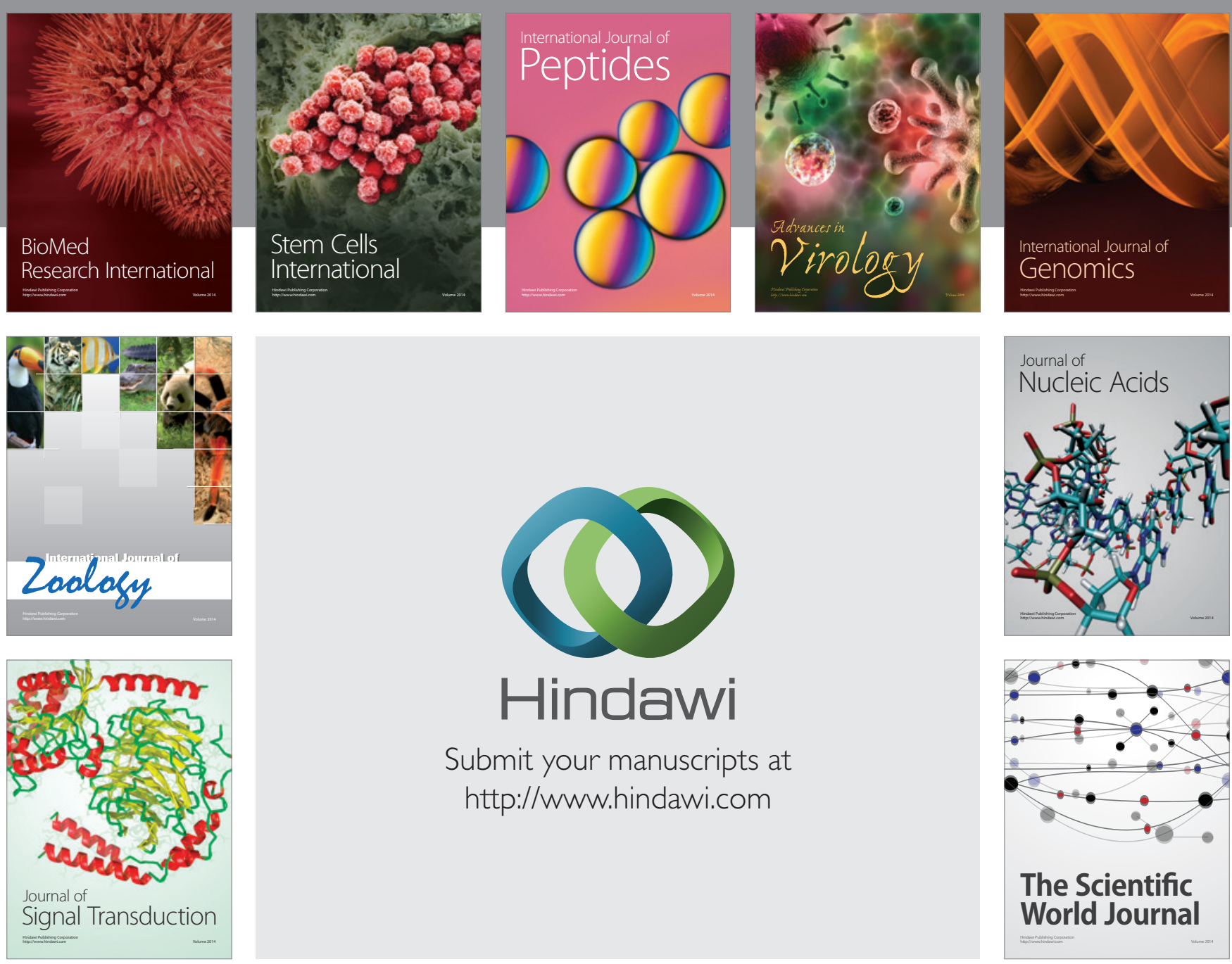

Submit your manuscripts at

http://www.hindawi.com
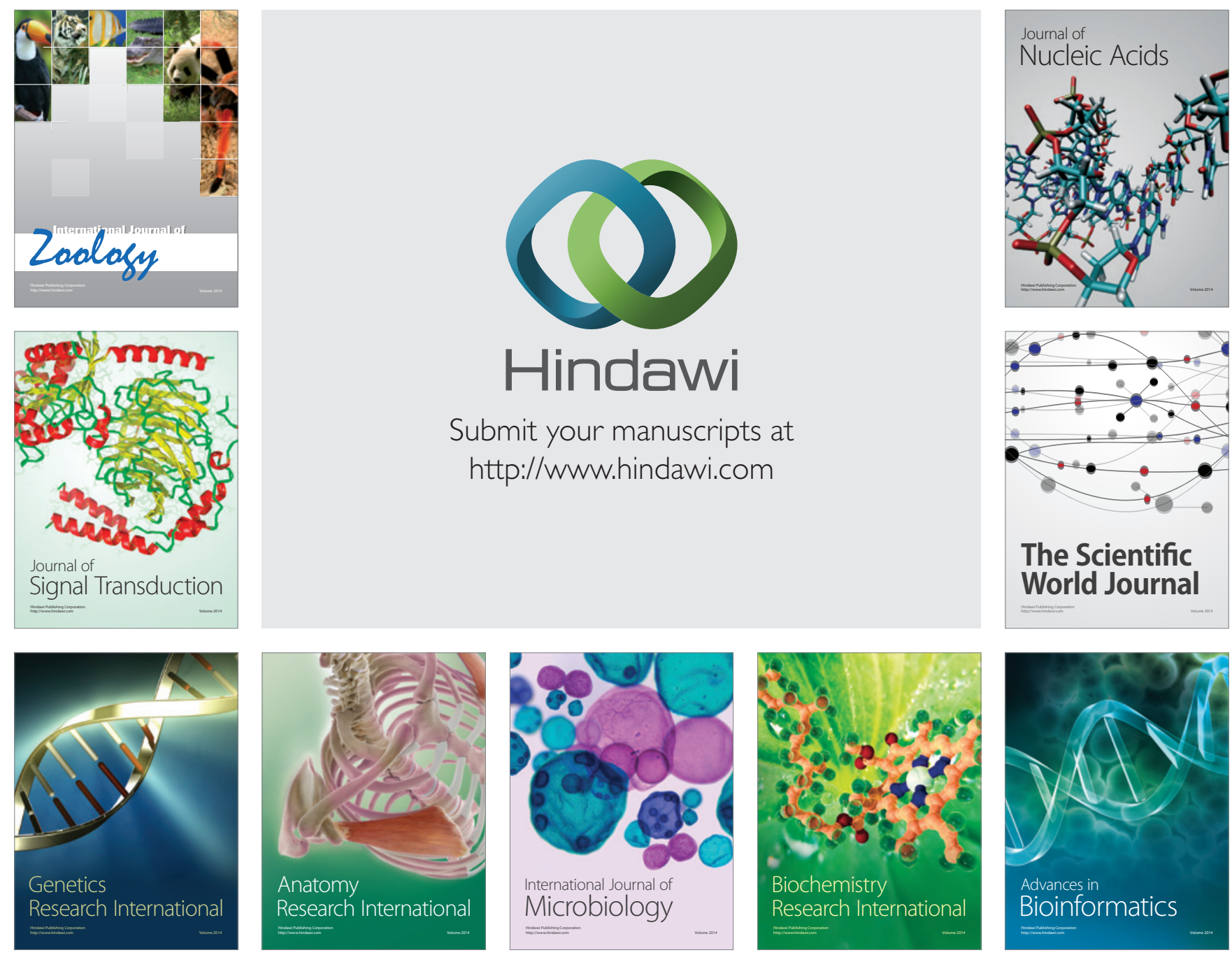

The Scientific World Journal
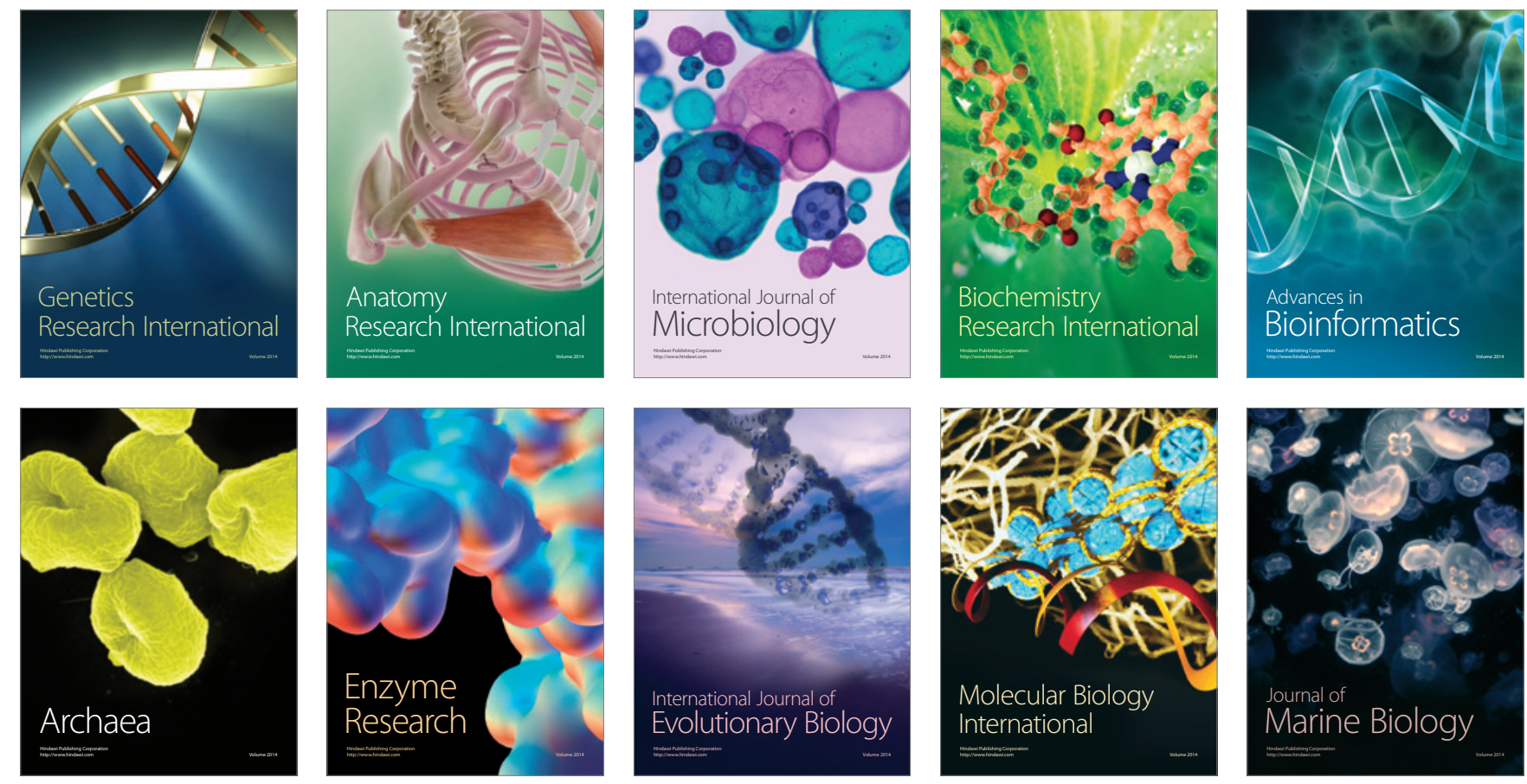